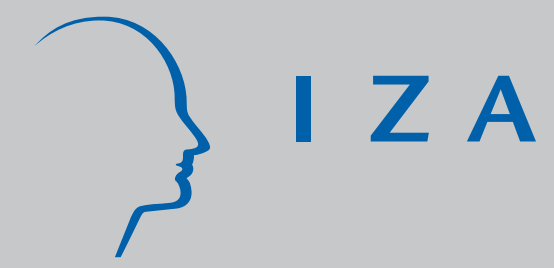

IZA DP No. 989

Are Young and Small Firms Hothouses

for Nascent Entrepreneurs?

Evidence from German Micro Data

J oachim Wagner

J anuary 2004 


\title{
Are Young and Small Firms Hothouses for Nascent Entrepreneurs? Evidence from German Micro Data
}

\author{
Joachim Wagner \\ University of Lueneburg, HWWA \\ and IZA Bonn \\ Discussion Paper No. 989 \\ January 2004
}

IZA

P.O. Box 7240

D-53072 Bonn

Germany

Tel.: +49-228-3894-0

Fax: +49-228-3894-210

Email: iza@iza.org

This Discussion Paper is issued within the framework of IZA's research area Mobility and Flexibility of Labor. Any opinions expressed here are those of the author(s) and not those of the institute. Research disseminated by IZA may include views on policy, but the institute itself takes no institutional policy positions.

The Institute for the Study of Labor (IZA) in Bonn is a local and virtual international research center and a place of communication between science, politics and business. IZA is an independent, nonprofit limited liability company (Gesellschaft mit beschränkter Haftung) supported by Deutsche Post World Net. The center is associated with the University of Bonn and offers a stimulating research environment through its research networks, research support, and visitors and doctoral programs. IZA engages in (i) original and internationally competitive research in all fields of labor economics, (ii) development of policy concepts, and (iii) dissemination of research results and concepts to the interested public. The current research program deals with (1) mobility and flexibility of labor, (2) internationalization of labor markets, (3) welfare state and labor market, (4) labor markets in transition countries, (5) the future of labor, (6) evaluation of labor market policies and projects and (7) general labor economics.

IZA Discussion Papers often represent preliminary work and are circulated to encourage discussion. Citation of such a paper should account for its provisional character. A revised version may be available on the IZA website (www.iza.org) or directly from the author. 
IZA Discussion Paper No. 989 January 2004

\title{
ABSTRACT
}

\section{Are Young and Small Firms Hothouses for Nascent Entrepreneurs? Evidence from German Micro Data*}

\begin{abstract}
Using a large recent representative sample of the German population this paper contributes to the entrepreneurship literature by empirically testing the hypothesis that young and small firms are hothouses for nascent entrepreneurs. The empirical estimation takes the rare events nature of becoming a nascent entrepreneur and the regional stratification of the sample into account. Controlling for various individual characteristics and attitudes (sex, age, risk aversion, presence of a role model in the family, and the width of professional background) we illustrate both the statistical significance and the economic importance for entrepreneurship of work experience in a firm that is both young and small.
\end{abstract}

JEL Classification: J23, R12

Keywords: entrepreneurship, young and small firms, rare events logit, Germany

Joachim Wagner

University of Lueneburg

Institute of Economics

21332 Lueneburg

Germany

Email: wagner@uni-lueneburg.de

\footnotetext{
${ }^{*}$ Research for this paper was done as part of the project Regional Entrepreneurship Monitor REM Germany financially supported by the German Research Foundation (DFG WA 610/2-1/2 and STE $628 / 7-1 / 2$ ). Many thanks to Michael Fritsch for a number of helpful suggestions on an earlier version; the usual disclaimer applies.
} 


\section{Motivation}

A stylised fact emerging from a vast number of empirical studies on the inter-regional differences in new firm formation is that the start-up rate in a region tends to be positively related to the share of employees working in small firms, or the proportion of small firms among all firms in the region (see, e.g., Mason 1991, Audretsch and Fritsch 1994, Gerlach and Wagner 1994, Reynolds, Storey and Westhead 1994, Armington and Acs 2002). A similar point has been made in studies dealing with inter-industry differences in new firm formation (see, e.g., Beesley and Hamilton). A theoretical explanation for this empirical regularity argues that working in a small firm tends to provide employees with a much more relevant experience for starting a new business (e.g., contacts with customers, and with the owner of the firm who therefore provides a role model to follow) than working in a large firm (see, e.g., Johnson 1986 and Mason 1991).

If this arguments holds one should expect that people who are working in a small firm (or did so in the past) should have a higher propensity to step into self-employment than others who work(ed) for a large enterprise. A similar argument can be made for those who work(ed) in young firms compared to those in old firms: Through a close contact to a successful entrepreneur people in a young firm have the opportunity to gather information about the transition from paid employment to self employment with all its problems, and about possible solutions (see, e.g., Sorensen and Audia 2000). The "employer-as-a-role-model" argument put forward in the context of the small firm should be even more relevant here, because not all small firms are young (and, therefore, not all owners of small firms are role models for potential starters of new firms today), but most of the young firms are small. And we expect it to be most relevant in the case of work experience gathered in a young and small firms.

Evidence on the ceteris paribus role played by the size and age of the firm a person is or has been working in for the decision to start a new business is scarce. To the best of my knowledge, Blanchflower and Meyer (1994) provide the only econometric study looking at the ceteris paribus impact of firm size on the transition into self-employment; for a sample of Australians, they find that the probability to step into self-employment decreases with firm size. The role played by firm age, and by young and small firms, for the individual decision to start a new business has not been investigated econometrically before.

This paper attempts to fill this gap in the entrepreneurship literature by empirically testing the hypothesis that young and small firms are hothouses for nascent entrepreneurs, controlling for various individual characteristics and attitudes (sex, age, risk aversion, presence of a role model in the family, and the width of professional background). 
The rest of the paper is organised as follows: Section two introduces the data set and provides evidence from descriptive statistics. Section 3 discusses the specification of the empirical model and presents the results from the econometric investigation. Section 4 concludes.

\section{Data and descriptive statistics}

The data used in this paper are taken from a representative survey of the population aged 18 to 64 in 11 (out of 97) so-called planning regions in Germany that was conducted using computer assisted telephone interviewing by TNS EMNID, a leading opinion research institute, between June and August 2003. This survey is part of the research project Regional Entrepreneurship Monitor (REM) Germany 2003 which focuses on the extent of the difference in entrepreneurial activities between regions in Germany, its determinants, and its consequences for regional development. ${ }^{1}$ The data set contains information on 12.000 people. ${ }^{2}$ The questionnaire asked for socio-demographic characteristics (e.g., sex, age, employment status, education, fields of professional experience) and a number of items related to entrepreneurial activities (e. g., whether the interviewee is currently engaged in starting an own business). ${ }^{3}$

In the empirical model discussed in the next section we regress the observed decision whether to start a new business or not on the age and size of the firm the interviewee is currently working in or worked in before, and on a set of personal characteristics and attitudes. Selection of the elements included in the empirical model are, at least in part, data driven. Although we had full control over the design of the questionnaire used in the REM survey, we were unable to collect information on all individual characteristics that are important for the decision under consideration due to budget constraints (that limited the time per interview and the number of items to be included) and the willingness of the interviewees to report information on issues like the amount of personal wealth. Effects of variables not included in the empirical model are covered by the error term. Frankly, this might lead to an omitted variables bias - a problem common to many (all?) econometric investigations.

That said, we will now turn to a discussion of the variables measured at the firm level and at the individual that are included in our empirical model.

\footnotetext{
${ }^{1}$ For further information about the REM project see Bergmann et al. (2002). REM is closely related to GEM, the Global Entrepreneurship Monitor, a multi-country study that investigates the same topics at a national level (see Reynolds et al. 2000).

${ }^{2}$ The data will be made available for public scientific use after the completion of the REM project.

${ }^{3}$ An English version of the questionnaire is not yet available; a German version is available from the author on request.
} 
In the survey the interviewee was asked whether she/he is (alone or with others) actively involved in starting a new business that will (as a whole or in part) belong to her/him, and whether this business did not pay full time wages or salaries for more than three months to anybody (including the interviewee). Those who answered in the affirmative are considered to be nascent entrepreneurs. ${ }^{4}$ Interviewees who are currently working in a private sector firm and who are not nascent entrepreneurs are considered to be employees. The empirical model considers the decision between these two alternatives only; self-employed, public sector employees, and people out of the labor force are excluded from the sample.

To start with the characteristics of the firm which are at the core of this investigation we consider both firm size and firm age. Firm age is measured in years. Given that we do not expect that it matters whether a firm is, say, 48, 83 or 145 years old, we defined five age classes: 0 to 5 years, 6 to 10 years, 11 to 15 years, 16 to 20 years, and 21 years or older. Furthermore, we defined a young firm to be at most 10 years old. Firm size is measured by the number of employees working in a firm. ${ }^{5} \mathrm{We}$ defined size classes using a classification scheme common in German official statistics, i.e. 1 to 20 employees, 21 to 49 employees, 50 to 99 employees, 100 to 249 employees, 250 to 499 employees, and 500 employees or more. Firms with less than or equal to 20 employees are considered to be small firms. Furthermore, we looked at the group of firms that are both young and small according to our definition.

Descriptive statistics for these variables are given in the upper part of table I. Nascent entrepreneurs are (or have been) more often employed in younger and smaller firms than employees. Both the mean firm age and firm size is much smaller for the group of nascents, and the shares of nascents which are from the lowest firm age and the lowest firm size class are much higher than the respective shares of employees. The same holds for the percentage of interviewees from young small firms: Nearly every third nascent entrepreneur comes from a firm of this type compared to about every tenth employee.

\footnotetext{
${ }^{4}$ This definition of a nascent entrepreneur is identical to the definition used in the multi-country GEM project mentioned in footnote 1; see Reynolds et al. 2000, p.9.

${ }^{5}$ In the survey some interviewees reported an incredibly high number of employees in their firm (up to 700.000 !). From the raw data we get an average firm size of 6.774 employees. These figures are nonsense. According to the Federal Statistical Office in 1999 there were only 749 firms in the industrial sector that had 1.000 or more employees. These very large firms employed 2.6 million persons - or 3.471 on average. In 2000, the average number of employees in all industrial establishments was about 130. Firms from private services and from building and construction tend to be much smaller on average (see Statistisches Bundesamt 2002, p. 289ff.). I decided to drop all (195) cases with a firm size that exceeds 17.000 employees - about five times the average number of employees among the group of the largest firms in the manufacturing sector. A comparison of the descriptive statistics from the whole sample and the reduced sample reveals no differences apart from the average firm size; the table is available on request.
} 
[Table I near here]

As regards the individual characteristics and attitudes, we include the following variables:

- Sex (a dummy variable taking the value one if the interviewee is male). Hypothesis: It is a stylised fact that men do have a higher propensity to step into selfemployment than women, at least in Germany. Sex is included in our empirical model to control for this difference in behaviour between men and women, and we expect a positive sign for the estimated coefficient of the dummy variable.

- Age (measured in years). Hypothesis: On the one hand, age is a proxy variable for personal wealth - the older a person is, the longer is the potential period to accumulate wealth. Given that young firms are often constrained by lack of credit because banks usually demand collateral to finance investments, a certain amount of wealth is crucial for starting a new business (see Evans and Jovanovic 1989). This leads to the expectation of a positive sign of the estimated coefficient of the age variable. On the other hand one has to acknowledge that starting a new business often leads to high sunk costs - think of all the effort to set up a business plan, doing market research, dealing with legal and administrative problems, etc. The shorter the expected life span of the new business, the shorter is the period over which these sunk costs can be earned back. To put it differently, setting up a new business with high sunk costs is more attractive at the age of 45 than at the age of 60 , ceteris paribus. This leads to the expectation of a negative sign of the estimated coefficient of the age variable. Given these two opposite influences of age on the propensity to become an entrepreneur it is an empirical question whether one dominates the other, or whether both net out (see Evans and Leighton 1989).

- Fear of failure a reason not to start (a dummy variable taking the value one if the interviewee agreed that fear to fail would prevent him from founding a firm). Hypothesis: If the interviewee answered this question in the affirmative we consider this as an indicator of a high degree of risk aversion, and we expect a negative impact on the probability of becoming a nascent entrepreneur (see Kihlstrom and Laffont 1979).

- Role model (a dummy variable taking the value one if there is or was at least one self-employed in the family of the interviewee). We expect a positive impact of contact with such a 'role model' (see Sternberg 2000, p. 60).q

In a recent paper Lazear (2002) proposed the jack-of-all-trades view of entrepreneurship. Based on a coherent model of the choice between self-employment and paid employment he shows that having a background in a large number of different roles increases the probability of becoming an entrepreneur. The intuition behind this proposition is that entrepreneurs must have sufficient knowledge in a variety of areas to 
put together the many ingredients needed for survival and success in a business, while for paid employees it suffices and pays to be a specialist in the field demanded by the job taken. The variety of professional experience of an interviewee that is at the heart of Lazear's theory of entrepreneurship is measured by two variables:

- The survey includes a tailor-made question asking in how many different professional fields the interviewee has been active in the past, explaining that this does not mean the number of employers she/he worked for. The answer is included in the empirical investigation as the number of fields of experience.

- The survey collects information about professional degrees completed after school, i.e. whether or not the interviewee successfully passed apprenticeship, managed to qualify formally as a master craftsperson, or received a degree from a polytech or university. The number of professional degrees (ranging from zero to three) is included as a variable in the empirical investigation.

Descriptive statistics for these variables are given in the lower part of table I. Given that in this study all these variables act as control variables only, we will only briefly comment on the figures reported. Compared to employees among the nascent entrepreneurs we find more males, less people with a high degree of risk aversion, and more persons which have at least one self-employed as a member of their family. Furthermore, on average nascents tend to be younger, have more fields of experience, and (but only slightly) a higher number of professional degrees. All these results are in line with our priors.

\section{Results of the econometric study}

The ceteris paribus role played by firm age and firm size in determining the probability of becoming a nascent entrepreneur when characteristics and attitudes of the interviewee are controlled for is investigated in an econometric model with a dummy endogenous variable taking the value one if a person is a nascent entrepreneur, zero otherwise.

Starting a new business is a rare event; only 132 (or 3.6 percent) of all persons included in the sample are nascent entrepreneurs. Application of standard textbook probit or logit methods to estimate the empirical models is not appropriate here. Gary King and Langche Zeng (2001a, 2001b) recently developed a version of the logit model to compute unbiased estimates in a situation like this. This method - labelled Rare Events Logistic Regression, or RELOGIT - is applied here. RELOGIT estimates the same logit model as the standard logit procedure, but uses an estimator that gives lower mean square error in the presence of rare events data for coefficients, probabilities, and other quantities of interest. Furthermore, to take the survey design into account and to allow that the observations might be dependent within a planning region, the variances 
of the estimated coefficients were estimated with the region as a cluster. ${ }^{6}$ Note that spatial auto-correlation is not an issue in our study because the planning regions are scattered all over Germany.

In the econometric investigation three different variants of the empirical model were estimated. All variants include an identical set of control variables (for sex, age, risk aversion, presence of a role model, and numbers of fields of experience and professional degrees), but they differ in the way firm age and firm size is measured. Model A includes both firm age (years) and firm size (number of employees) as a continuous variable; furthermore, both variables are included in squares, too, to test for non-linear relationships. Model B has dummy variables for the five age classes and six size classes (using the highest age and size class as the reference group); Model $\mathrm{C}$ includes dummy variables for young firms (up to ten years old) and small firms (up to 20 employees), and an interaction term indicating young and small firms. Results are reported in table II.

\section{[Table II near here]}

In Model A firm size has no influence at all on the probability of being a nascent entrepreneur, while the estimated coefficients for the firm age variables point to a $\mathrm{u}$ shaped relationship. Note, however, that some 95 percent of all observations included in the regression lie before the estimated minimum of 112 years, so that the u-shaped profile should be interpreted as pointing out that the probability of being a nascent entrepreneur declines with increasing firm age at a decreasing rate. ${ }^{7}$ Model $\mathrm{B}$ gives a similar picture. None of the firm size class dummies is statistically significantly different from zero at any conventional level; compared to firms that are older than twenty years, (former) employees from firms that are up to 5 years or between 6 and 10 years old have a higher probability of being a nascent entrepreneur ceteris paribus, while this is not the case for employees from firms in age class 3 and 4.

Results for model $\mathrm{C}$ reveal that it is not firm age alone that matters but a low firm age combined with a small firm size: While the estimated coefficient for the small firm dummy is statistically insignificant, and the estimated coefficient for young firms is

\footnotetext{
${ }^{6}$ All computations were done with Stata 8.1 (see StataCorp 2003) using the relogit ado-file available from Gary King's homepage at Harvard $<$ http://gking.harvard.edu $>$.

${ }^{7}$ We note in passing that all the control variables have the expected signs, and all but the number of professional fields are statistically significant at the 10 percent error level or better; this holds for the other two models estimated, too. Furthermore, all models were estimated with the age of the person and the age of the person squared, too. Here we find evidence for a u-shaped profile; both estimated coefficients, however, were never statistically different from zero at an error level of less than 13 percent (details are available on request). Therefore, age of the person is included in levels in the emprical models only.
} 
positive and statistically significant at an error level of 7.8 percent, the interaction term indicating firms that are both young and small is positive and highly statistically significant. To put it differently, while 55 percent of all young firms in our sample have up 20 employees, 40 percent of all small firms are older than 20 years, and the hothouse-function is performed (more) by the younger and smaller fraction of firms, not by the smaller and older ones.

In a sensitivity analysis the empirical models were estimated without the firm age variables. The estimated regression coefficients for firm size and firm size squared are both statistically insignificant (with prob-values of 0.252 and 0.549 , respectively) in a version of model A without firm age and firm age squared. If the firm age class dummies are dropped from model B the estimated coefficient of the firm size class 1 dummy variable is +0.562 with a prob-value of 0.012 (all other size class dummies are insignificant with prob-values of 0.396 or higher). In model $\mathrm{C}$ without the young firm dummy (and the interaction term of young and small firm) the small firm dummy has a positive coefficient of 0.585 with a prob-value of 0.000 . From this sensitivity analysis it follows that ignoring firm age leads to the (wrong) conclusion that working in small firms with up to 20 employees is positively related to the probability of becoming a nascent entrepreneur. To put it differently, the firm size variable tends to pick up a part of the influence of firm age in regression models where firm age is excluded. Technically speaking, the positive effect of firm size is a textbook example for an omitted variable bias.

Discussion of results hitherto was limited to the statistical significance of the estimated coefficients and the direction of influence conducted by the variables. Information on the extent of this influence, or on the economic importance, however, is even more important. Evidently, a variable that has no statistically significant impact can be ignored from an economic point of view, but the opposite is not true: A variable that is highly significant statistically might not matter at all economically - if the estimated probability for becoming a nascent entrepreneur diminishes by 0.00001 percent when a firm is, for example, 25 instead of 5 years old, we can ignore firm age in any discussion on nascent entrepreneurs irrespective of any high level of statistically significance indicated by the prob-value.

Unfortunately, the estimated coefficients from a rare events logit model (or for any other non-linear model) can not easily be used for statements about the size of the ceteris paribus effect of a change of the value of an exogenous variable (e.g., an increase in firm age that leads to crossing the threshold from young to old firms) on the value of the endogenous variable (e.g., the probability of becoming a nascent entrepreneur), because the size of this effects depends on both the value of the exogenous variable under consideration and on the values of all other variables in the model (see Long and Freese, 2001, 87ff.). 
A way to ease interpretation of the estimation results is to compute the estimated values of the endogenous variable (here: the probability of becoming a nascent entrepreneur) for a person with certain characteristics and attitudes, and to show how a change in the value of one exogenous variable at a time changes the estimated probability.

For expository purposes, we define a reference person - call it person 1 - which is male, 40 years old, has four fields of experience, holds one professional degree, is not highly risk averse, has at least one self-employed in the family, and works (or worked) neither in a small nor in a young firm. According to the results reported for model $\mathrm{C}$ in table II the estimated probability for person 1 to become a nascent entrepreneur is 6.4 percent.

If we consider person 2 who is identical to person 1 but who works (or worked) in a young but not small firm, the estimated probability is 8.5 percent. If we look at person 3 who is again identical to person 1 and person 2 but who works (or worked) in a young and small firm, the estimated probability to become a nascent entrepreneur is much higher - 19.9 percent. Note that the large differences between the estimated probabilities for person 3 and both person 1 and person 2 are statistically significant at an error level of 5 percent.

This small simulation exercise shows that it matters to work in a firm that is both young and small - and that it matters both statistically and economically. We note in passing that ignoring the firm age variable leads to the conclusion that the probability of becoming a nascent entrepreneur increases from 6.6 percent to 11.2 percent for a person (with the characteristics and attitudes detailed above) who works in a small firm compared to an identical person who does not. This again illustrates the bias caused by ignoring firm age in an empricial model of nascent entrepreneurship.

\section{Conclusions}

Using a large recent representative sample of the German population this paper empirically tests the hypothesis that young and small firms are hothouses for nascent entrepreneurs. Controlling for various individual characteristics and attitudes (sex, age, risk aversion, presence of a role model in the family, and the width of professional background) it demonstrates both the statistical significance and the economic importance for entrepreneurship of work experience in a firm that is both young and small.

An important implication of this result is that, given that entrepreneurs tend to found their new business in the region they live in, regions with more young and small firms today will have more young and small firms tomorrow (when the successfull young and small firms of today will be old and many of them will be large, while the 
unsuccessful will be out of business) - and that regions without a large population of these hothouses for nascent entrepreneurs will not have much of them in the future. In a sense, therefore, this paper provides micro-econometric evidence for the thesis that entrepreneurship breeds entrepreneurship both at the individual level (see the positive impact of the presence of a role model in the family) and at the regional level.

Furthermore, this paper demonstrates that because firm age matters results from empirical studies including firm size only give biased estimates regarding the role of firm size. This once more illustrates the warning given by Brown, Hamilton and Medoff (1990, p. 91): Do not judge firms by their size alone!

\section{References}

Armington, Catherine and Zoltan J. Acs (2002), The Determinants of Regional Variation in New Firm Formation. Regional Studies 36, 33-45.

Audretsch, David B. and Michael Fritsch (1994), The Geography of Firm Births in Germany. Regional Studies 28, 359-365.

Beesley, M. E. and R. T. Hamilton (1984), Small Firms' Seedbed Role and the Concept of Turbulence. Journal of Industrial Economics XXXIII, 217-231.

Bergmann, Heiko, Andrea Japsen and Christine Tamásy (2002), Regionaler Entrepreneurship Monitor (REM) - Gründungsaktivitäten und Rahmenbedingungen in zehn deutschen Regionen. Universität zu Köln and Universität Lüneburg.

Blachflower, David. G. and Bruce D. Meyer (1994), A Longitudinal Analysis of the Young Self-Employed in Australia and the United States. Small Business Economics 6, 1-19.

Brown, Charles, James Hamilton, and James Medoff (1990), Employers Large and Small. Cambridge, Mass.: Harvard University Press.

Evans, David S. and Boyan Jovanovic (1989), An Estimated Model of Entrepreneurial Choice under Liquidity Constraints. Journal of Political Economy 97, 808-827.

Evans, David S. and Linda S. Leighton (1989), Some Empirical Aspects of Entrepreneurship. American Economic Review 79, 519-535.

Gerlach, Knut and Joachim Wagner (1994), Regional differences in small firm entry in manufacturing industries: Lower Saxony, 1979 - 1991. Entrepreneurship \& Regional Development 6, 63-80.

Johnson, P. S. (1986), New Firms: An Economic Perspective. London: Allen and Unwin.

Kihlstrom, Richard E. and Jean-Jacques Laffont (1979), A General Equilibrium Entrepreneurial Theory of Firm Formation Based on Risk Aversion. Journal of Political Economy 87, 719-748. 
King, Gary and Langche Zeng (2001a), Logistic Regression in Rare Events Data, Political Analysis 9 (2), 137-163.

King, Gary and Langche Zeng (2001b), Explaining Rare Events in International Relations, International Organization 55 (3), 693-715.

Lazear, Edward P. (2002), Entrepreneurship. National Bureau of Economic Research Working Paper 9109, August.

Long, J. Scott and Jeremy Freese (2001), Regression Models for Categorical Dependent Variables using Stata. College Station, TX: Stata Press.

Mason, C. (1991), Spatial variations in enterprise: the geography of new firm formation. In R. Burrows (ed.) Deciphering the Enterprise Culture. Entrepreneurship, Petty Capitalism and the Restructuring of Britain. London and New York: Routledge.

Reynolds, Paul D. et al. (2000), GEM Global Entrepreneurship Monitor. 2000 Executive Report. Kansas City: Kauffman Center for Entrepreneurial Leadership.

Reynods, Paul D., David Storey and Paul Westhead (1994), Cross-national Comparisons of the Variation in New Firm Formation Rates. Regional Studies 28, 443-356.

Sorensen, Olav and Pino G. Audia (2000), The Social Structure of Entrepreneurial Activity: Geographic Concentration of Footwear Production in the United States, 1940 - 1989. American Journal of Sociology 106, 424-462.

StataCorp (2003), Stata User's Guide, Release 8. College Station, TX: Stata Corporation.

Statistisches Bundesamt (2002), Datenreport 2002, Zahlen und Fakten über die Bundesrepublik Deutschland. Bonn: Bundeszentrale für politische Bildung.

Sternberg, Rolf (2000), Entrepreneurship in Deutschland, Das Gründungsgeschehen im internationalen Vergleich, Länderbericht Deutschland 1999 zum Global Entrepreneurship Monitor. Berlin: edition sigma. 


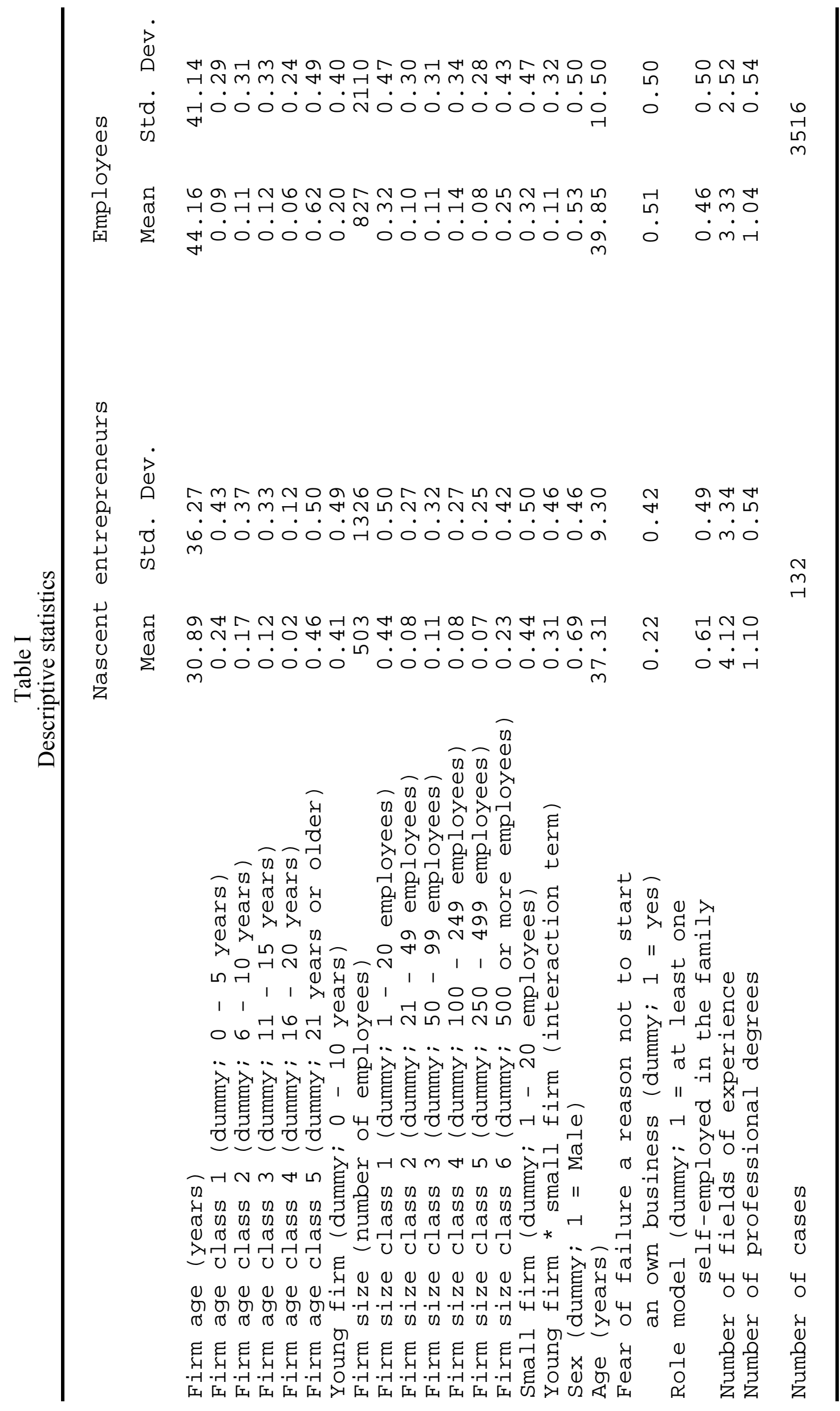


Table II

Rare events logit estimates for being a nascent entrepreneur

\begin{tabular}{|c|c|c|c|}
\hline & Model A & Model B & Model C \\
\hline Firm age (years) & $\begin{array}{r}-0.022 \\
0.001\end{array}$ & & \\
\hline Firm age (squared) & $\begin{array}{l}9.84 e-5 \\
0.043\end{array}$ & & \\
\hline $\begin{array}{l}\text { Firm age class } 1 \\
\text { (dummy; } 0-5 \text { years) }\end{array}$ & & $\begin{array}{l}1.095 \\
0.000\end{array}$ & \\
\hline Firm age class 2 & & 0.626 & \\
\hline (dummy; $6-10$ years) & & 0.001 & \\
\hline Firm age class 3 & & 0.291 & \\
\hline (dummy; $11-15$ years) & & 0.200 & \\
\hline $\begin{array}{l}\text { Firm age class } 4 \\
\text { (dummy; } 16-20 \text { years) }\end{array}$ & & $\begin{array}{r}-0.080 \\
0.266\end{array}$ & \\
\hline $\begin{array}{l}\text { Young firm } \\
\text { (dummy } 0-10 \text { years) }\end{array}$ & & & $\begin{array}{l}0.309 \\
0.078\end{array}$ \\
\hline $\begin{array}{l}\text { Firm size } \\
\text { (number of employees) }\end{array}$ & $\begin{array}{l}-1.88 e-6 \\
0.992\end{array}$ & & \\
\hline Firm size (squared) & $\begin{array}{l}-4.42 e-9 \\
0.818\end{array}$ & & \\
\hline & & 0.246 & \\
\hline (dummy; $1-20$ employees) & & 0.255 & \\
\hline Firm size class 2 & & -0.264 & \\
\hline (dummy; 21 - 49 employees) & & 0.640 & \\
\hline Firm size class 3 & & 0.211 & \\
\hline (dummy; 50 - 99 employees) & & 0.602 & \\
\hline Firm size class 4 & & -0.380 & \\
\hline (dummy; $100-249$ employees) & & 0.293 & \\
\hline $\begin{array}{l}\text { Firm size class } 5 \\
\text { (dummy; } 250-499 \text { employees) }\end{array}$ & & $\begin{array}{r}-0.018 \\
0.962\end{array}$ & \\
\hline Small firm & & & -0.105 \\
\hline (dummy; $1-20$ employees) & & & 0.627 \\
\hline $\begin{array}{l}\text { Young firm * small firm } \\
\text { (interaction term) }\end{array}$ & & & $\begin{array}{l}1.078 \\
0.000\end{array}$ \\
\hline Sex & 0.658 & 0.652 & 0.659 \\
\hline (dummy; $1=$ Male) & 0.000 & 0.000 & 0.000 \\
\hline Age (years) & $\begin{array}{r}-0.019 \\
0.054\end{array}$ & $\begin{array}{r}-0.018 \\
0.069\end{array}$ & $\begin{array}{r}-0.018 \\
0.076\end{array}$ \\
\hline Fear of failure a reason not to start & -1.118 & -1.100 & -1.110 \\
\hline an own business (dummy; $1=$ yes) & 0.000 & 0.000 & 0.000 \\
\hline Role model (dummy; $1=$ at least one & 0.415 & 0.434 & 0.425 \\
\hline self-employed in the family & 0.089 & 0.083 & 0.080 \\
\hline Number of fields of experience & 0.076 & 0.076 & 0.077 \\
\hline Number of professional degrees & $\begin{array}{l}0.000 \\
0.166\end{array}$ & $\begin{array}{l}0.000 \\
0.176\end{array}$ & $\begin{array}{l}0.000 \\
0.178\end{array}$ \\
\hline & 0.236 & 0.192 & 0.186 \\
\hline Constant & -2.630 & -3.567 & -3.522 \\
\hline & 0.000 & 0.000 & 0.000 \\
\hline Number of cases & 3648 & 3648 & 3648 \\
\hline
\end{tabular}

Note: Prob-values are reported below the estimated coefficients 


\section{IZA Discussion Papers}

\begin{tabular}{|c|c|c|c|c|}
\hline No. & Author(s) & Title & Area & Date \\
\hline 975 & $\begin{array}{l}\text { A. Constant } \\
\text { K. F. Zimmermann }\end{array}$ & Occupational Choice across Generations & 1 & $12 / 03$ \\
\hline 976 & $\begin{array}{l}\text { J. D. Angrist } \\
\text { K. Lang }\end{array}$ & $\begin{array}{l}\text { Does School Integration Generate Peer Effects? } \\
\text { Evidence from Boston's Metco Program }\end{array}$ & 6 & $01 / 04$ \\
\hline 977 & $\begin{array}{l}\text { M. Corak } \\
\text { G. Lipps } \\
\text { J. Zhao }\end{array}$ & $\begin{array}{l}\text { Family Income and Participation in Post- } \\
\text { Secondary Education }\end{array}$ & 5 & $01 / 04$ \\
\hline 978 & $\begin{array}{l}\text { J. T. Addison } \\
\text { P. Portugal }\end{array}$ & $\begin{array}{l}\text { How Does the Unemployment Insurance System } \\
\text { Shape the Time Profile of Jobless Duration? }\end{array}$ & 3 & $01 / 04$ \\
\hline 979 & $\begin{array}{l}\text { M. Moreno } \\
\text { H. Ñopo } \\
\text { J. Saavedra } \\
\text { M. Torero }\end{array}$ & $\begin{array}{l}\text { Gender and Racial Discrimination in Hiring: A } \\
\text { Pseudo Audit Study for Three Selected } \\
\text { Occupations in Metropolitan Lima }\end{array}$ & 1 & $01 / 04$ \\
\hline 980 & $\begin{array}{l}\text { H. Nopo } \\
\text { J. Saavedra } \\
\text { M. Torero }\end{array}$ & Ethnicity and Earnings in Urban Peru & 1 & $01 / 04$ \\
\hline 981 & H. Ñopo & Matching as a Tool to Decompose Wage Gaps & 1 & $01 / 04$ \\
\hline 982 & $\begin{array}{l}\text { I. Geishecker } \\
\text { H. Görg }\end{array}$ & $\begin{array}{l}\text { Winners and Losers: Fragmentation, Trade and } \\
\text { Wages Revisited }\end{array}$ & 2 & $01 / 04$ \\
\hline 983 & $\begin{array}{l}\text { D. Del Boca } \\
\text { M. Locatelli } \\
\text { D. Vuri }\end{array}$ & Child Care Choices by Italian Households & 3 & $01 / 04$ \\
\hline 984 & $\begin{array}{l}\text { W. Arulampalam } \\
\text { A. L. Booth } \\
\text { M. L. Bryan }\end{array}$ & $\begin{array}{l}\text { Are there Asymmetries in the Effects of Training } \\
\text { on the Conditional Male Wage Distribution? }\end{array}$ & 5 & $01 / 04$ \\
\hline 985 & $\begin{array}{l}\text { Š. Jurajda } \\
\text { H. Harmgart }\end{array}$ & When Are 'Female' Occupations Paying More? & 4 & $01 / 04$ \\
\hline 986 & $\begin{array}{l}\text { H. Brücker } \\
\text { P. Trübswetter }\end{array}$ & $\begin{array}{l}\text { Do the Best Go West? An Analysis of the Self- } \\
\text { Selection of Employed East-West Migrants in } \\
\text { Germany }\end{array}$ & 1 & $01 / 04$ \\
\hline 987 & $\begin{array}{l}\text { A. Ichino } \\
\text { G. Muehlheusser }\end{array}$ & $\begin{array}{l}\text { How Often Should You Open the Door? Optimal } \\
\text { Monitoring to Screen Heterogeneous Agents }\end{array}$ & 7 & $01 / 04$ \\
\hline 988 & M. Jansen & Can Job Competition Prevent Hold-Ups? & 7 & $01 / 04$ \\
\hline 989 & J. Wagner & $\begin{array}{l}\text { Are Young and Small Firms Hothouses for } \\
\text { Nascent Entrepreneurs? Evidence from German } \\
\text { Micro Data }\end{array}$ & 1 & $01 / 04$ \\
\hline
\end{tabular}

An updated list of IZA Discussion Papers is available on the center's homepage www.iza.org. 